特集 『生態系アセスメントの課題 一景観生態学からのアプローチー』

\title{
猛禽類からみた生態系アセスメント
}

西 浩司

新日本気象海洋株式会社大阪支店生態解析グル-プ テ 550-0002 大阪市西区江戸堀 3-2-23 (west@notes.metocean.co.jp)

\section{Methods and problem on environmental assessment for project implementation about the local ecosystem and raptors Koji NISHI}

Shin-nippon Meteorological and Oceanographical consultant Co.Ltd.,3-2-23 Edobori Nishi-ku,Osaka,550-0002 Japan

\section{はじめに}

平成 9 年に成立した環境影響評価法では，事業 の影響の予測・評価を動植物および生態系につい て行うこととされている．環境庁が示した基本的 事項によると，「地域を特徽づける生態系に関し， 上位性，典型性および特殊性の視点から注目され る生物種等を複数選び，それらの生態，種間関係， 生息地の環境などを調べて予測・評価する」とされ ている(幸丸,1999). あらゆる側面の詳細な調査は 不可能なため, 可能な限り近似できるものを選ば うということと解釈できる。

このうち上位性では,「生態系を構成する生物群 集において栄養段階の上位に位置する種」とされ ており, イヌワシ(Aquila chrysaetos), クマタカ (Spizaetus nipalensis), オオタカ(Accipiter gentilis)な どの大型の希少猛禽類や大型哺乳類が選定される ことが想定され, 最近の方法書や実施計画書でも, そのように記載されているものがある，猛禽類は 単に栄養段階の上位に位置するだけでなく, 地域 のいろいろな景観要素をまたがって利用している
という点, 比較的調査しやすい点で,アセスの上位 性としてふさわしいと思わ机る。山地で地表を動 き回る動物を選定した場合，その調査の困難さは 想像に難くない.

しかし，実際に猛禽類を指標に選び，その生態・ 分布・生活史・生息環境とその利用などの調査を行 い,その結果で的確に地域の生態系を把握し, 事業 の影響を予測・評価すること,および保全措置を実 施して, 事後評価を行うという一連の作業には，ま だ多くの課題が残っている.現在のアセスは, 事業 アセスであり，開発行為が前提になる。その上で影 響を予測して，どこで折り合えるか見当を付け，必 要な保全措置を可能な限り，そして現在の科学的 知見に照らして納得できる手法で実施して行くこ と，なおかつまだわからないことも多いのだとい う謙虚さが重要だと思われる。

行動範囲が広大な猛禽類では，生息環境そのも のである地域の景観構造と生息・繁殖の継続が密 接に関連していると考えられ, 最終的には, 猛禽類 を指標にしたアセスは，適切な地域の景観計画を

表 1.イヌワシ・クマタカの生態の特徵(環境庁,1996;山崎,1997 より整理)

\begin{tabular}{|c|c|c|}
\hline 項目 & イヌワシ & クマタカ \\
\hline つがい数 & 国内には約130つがいほどが生息 & 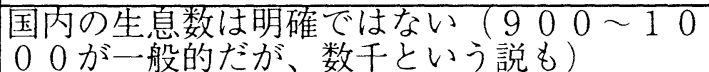 \\
\hline 棠笨場所 & 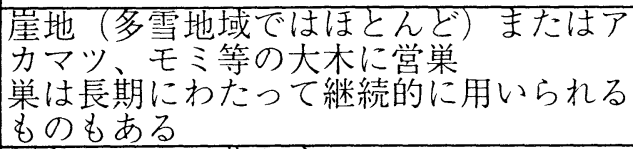 & 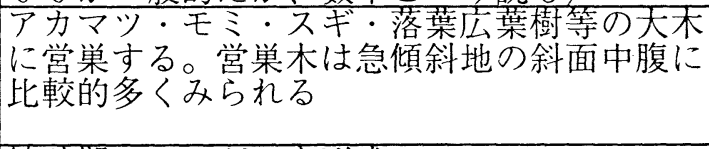 \\
\hline つがい形成 & 周年つがいで暮らす & 繁殖期のみつがいを形成 \\
\hline 行動圈・巣間距離 & 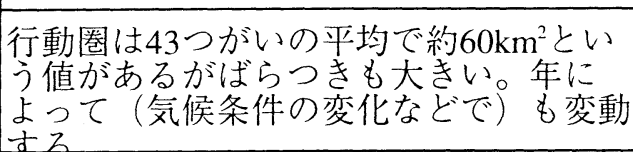 & 巣間距離は平均的には約 $4 \mathrm{k} \mathrm{m}$ \\
\hline ハンティング & $\begin{array}{l}\text { 草原や低木林など上空を飛翔しながら探 } \\
\text { 䬣し菍降下して獲物を捕獲する。冬季 } \\
\text { は落葉した樹林内も採餌場所とする }\end{array}$ & $\begin{array}{l}\text { 飛翔しながらあるいは步まって探餌し、林内 } \\
\text { や林縁部で獲物を捕獲する }\end{array}$ \\
\hline 嘅動物 & $\begin{array}{l}\text { ノウサギ・ヤマドリ・大型のへビが獲物 } \\
\text { の } 90 \% \text { 近くを占める }\end{array}$ & 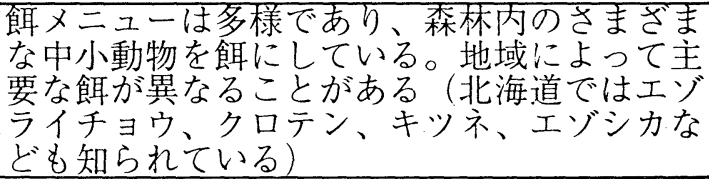 \\
\hline
\end{tabular}


立案して行くことにもつながる可能性がある．今 回は特にこの点に着目して, 生態系アセスメント で，上位性に猛禽類（特にイヌワシとクマタカ）を 扱うことの意義・課題などを考えてみたい。

イヌワシは，新潟などの多雪地域でつがい密度 が高いことが知られているが，これはなだれ地や 稜線の風衝草原などがイヌワワの採餌場として機 能していることが1つの要因と考えられ，我が国 においては，概ねイヌワシは山岳景観に適応して いると言える。しかし，イヌワシは伐採地や新植地 などオープンな場所にもよく現れるので，人間に よる山岳地域の土地利用の状況はイヌワシの生活 と大きく関わっている.九州では, イヌワシは 1 つ がいしか抢らず，長い間繁殖していない。繁殖でき ない原因は, 隔離分布・老齢化, 污染物質など他に もあるかも知れないが，九州の山地は本来の景観 は森林であり, それが林業の衰退とともに復活し, あるいは管理を放棄された草地が増え，イヌワシ のハビタットではなくなってきている（飭が取り 難い) 可能性がある.このつがいの行動圈が日本の 平均よりかなり広いことが，この可能性を支持し ている.

一方，クマタカは森林を利用する度合いが高い 点で,イヌワシと異なっている。森林が広がってい る地域では, 平均巣間距離約 $4 \mathrm{~km}$ というスケー ルでほぼ隙間なく分布し，稜線などで区切られる 地形単位で生活圈をつがいごとに分けているよう である。したがって個体が入れ替わっても生活圈 は固定的である可能性が高い。

クマタカが生息する森林は，全国的にみて非常 に多様で, 北海道の針広混交林, 本州の落葉樹林, スギ・ヒノキ植林地でも継続的な繁殖の実績があ り，必ずしも植林地は不適というわけではないよ うである.クマタカは主に林内で餌をとるが, 餌動 物が出てくる林縁部の利用も少なくない. 送電線 の鉄塔などにとまって，周辺の伐採地をねらうよ うな行動もみられる。林冠ギャップのあるところ は, 小型鳥類の食樹や昆虫も多いと思われるので, クマタカの利用度も高いことが想像される。狩り の現場を直接目視できることはまれであるが，テ レメトリー調査によって現在狩り行動に関する データが蓄積されつつある。

また，それぞれが日本の景観に適応した繁殖戦 略をとっている(イヌワシの兄弟殺し, 孵化時期の 選択，1 腹卵数など）と考えられており，そのよう な生態の違いが，わが国で本来北方の草原性のイ
ヌワシと熱帯雨林に起源をもつといわれるクマタ カが同居できる理由と思われる。

\section{アセスメントにおける猛禽類調査の内容}

アセスメントなどの環境調査で行われているイ ヌワシ・クマタカ調査について簡単にその現状に ふれておきたい，猛禽類調査では定点観察により 行動を追いかけて, 地図上に位置を, 行動内容をメ モで記録するのが一般的な方法である。テレメト リーは捕獲の難しさ等から研究以外では用いられ ることはほとんどない。従って目視によってでき るだけ細かくデータをとり，それにより猛禽類の 地域の利用状況の推定をどのように行うかが課題 となっている.

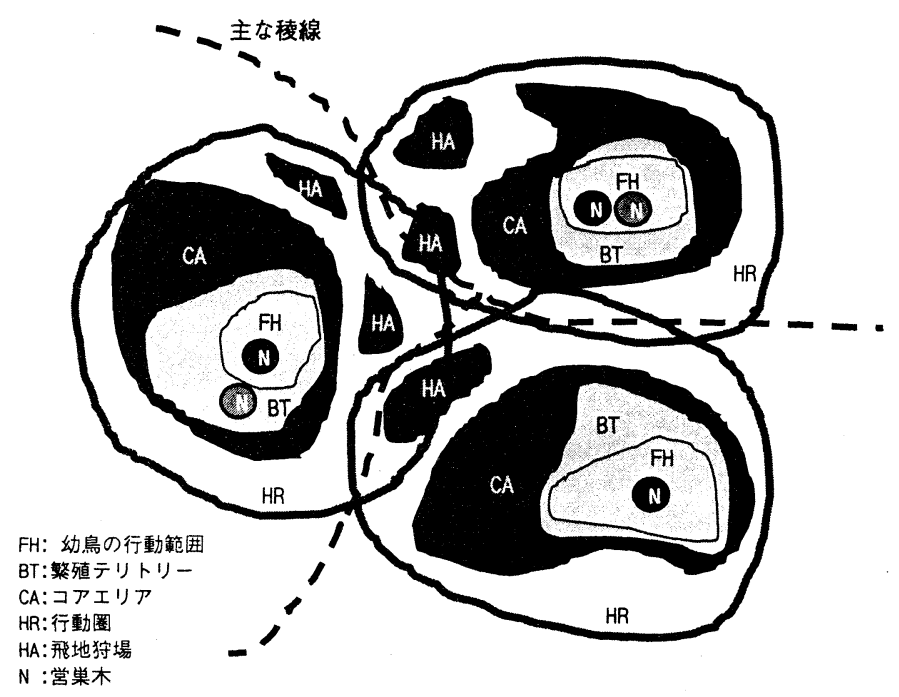

図 1.イヌワシの行動圈内部構造モデル（日本イヌ ワシ研究会・日本自然保護協会(1994)を一部改変)

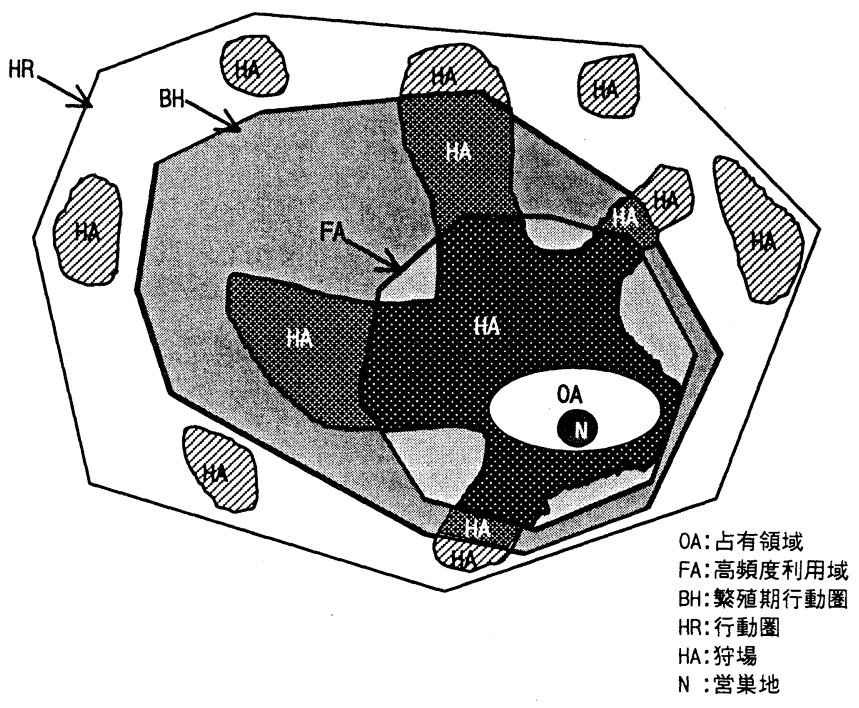

図 2.クマタカの行動圈内部構造モデル（クマタカ 生態研究グループ(1998)を一部改変) 
デー夕は，確認位置図および行動内容の表に整 理されるが, 観察条件は刻々变わり, また, クマ夕 カでは狩り行動を目視できることはまれであるた め，主に確認頻度や繁殖に関わる行動に着目して ハビタットの利用状況を推定することが行われて いる，環境調査においては，観察で得られた行動 デー夕を，これまでに提示されている行動圈の内 部構造 (地域の利用状況)のモデルにあてはめて解 釈していくという作業が行われている.

イヌワシでは，重要な場所（狩り場や営巣場所） を明らかにする上で，飛翔デー夕の頻度解析が有 効であると言われている。飛翔しながら慨を探す という生態を持つため, 飛翔ルートの偏りが, イヌ ワシにとって重要な場所を示唆するからである。 なお，巣への出入りのために通る場所が最も頻度 が高くなるが,そこは必ずしも餌場ではないので， 狩り場と植生の関係などを推定する際には注意が 必要である.しかし，イヌワシの場合は, 頻度高く 見られる場所は狩り場か営巣地周辺なので, アセ スメントを行うにあたっては，区別する必要はな いかも知れない.

一方，林内が主たる行動域であるクマタカやオ オタカでは, 目視観察の確認頻度から, 重要な地域 を求める方法の有効性は低い. 目視できるのは全 行動のほんの一部であり，しかも移動などが主で 利用場所の重要性を直接示唆しない可能性がある. クマタカ生態研究グループにより，いくつかの行 動パターン(特に繁殖に関係する行動) と行動圈の 内部構造モデルの線が相関することが明らかにな りつつあるので, 最近のアセスメント調査でも, 各 個体の行動から地域の利用状況を推定することが 実施され始めている。ただし, 目視ではモデルの線 をすべて明らかにはできず，行動圈も正確に求め ることは不可能とされており，アセスメント調査 でのデータの精度には限界がある。

このようなイヌワシ・クマタカによる地域の利 用度合の違いは，生息環境の不均一性に由来する と思われるので, 行動調查と並行して行動圈やな わばりの中の地形や地質, 植生などの現状の調査. 解析も始められている。残念ながら現時点では落 葉樹林, 植林地などの植生区分にとどまり，餌資源 量などまで踏みこまれた例はまだ少ない，伐採地 やカヤ場, 林道, 崩壊地, ギャップ, 沢などの林縁 部は, 狩り場として重要性は指摘されているが, 観 察データが精度上の限界を抱えており, 整理方法 が確立されているとはいえない.また, 狩り場より
も隣接する森林のほうが飭動物ソースとして重要 であることが想像されるが，その評価方法もこれ からの課題である.

生息地の景観を構成する農地, 宅地, 送電線など の土地利用の状況とともに，景観要素となる植物 群落については, 樹種, 管理状態, 大径木の分布, 下草や樹冠の状況なども, 直接・間接に猛禽類の利 用度合に影響していると思われるが，アセスメン トで通常実施される目視調査では，それらの分布 と行動の関係を明らかにすることは難しい，長期 間の繁殖率のデー夕と景観構造を対比させること も考えられるが，アセスメントではふつう時間と コストに制限があって難しい。このような事情か らこれまでの影響調査では，比較的わかりやすい 営巣場所に対する事業の影響の把握が主眼で行わ れてきているが，そこからは猛禽類にも配慮した 地域の景観計画のような発想は生まれにくい.

\section{生態系アセスメントにおける課題}

(1)アセスで猛禽類を上位性の注目種として選定す

\section{ることの意義}

オオタカでは, 飭が豊富で繁殖がうまく行って いても, 実は飭メニューはすっかり変わっていて, ドバトやムクドリばかりなっているかも知れない し，イヌワシも繁殖がうまく行っている地域は,伐 採が進んでいてノウサギが増えているところかも 知れないので, 猛禽類を生態系の健全性の指標と してよいか，アセスメントで上位性の注目種とし て選定していいかどうかは，調査上の課題もあっ て疑問が残る。しかし, 生態系全体を詳細に把握し て予測・評価することは不可能なので，ある事業が イヌワシやクマタカなどの猛禽類に影響するとし たら，それがすなわち生態系への影響の，すべてで はないが最も大きな側面であると考えればよい. 猛禽類の生息・繁殖状況に大きな変化がないこと が，生態系が健全に保たれていることを表すと仮 定することもできる.また, クマタカは林内の多様 な飭動物を利用しているので，地域の生物多様性 保全の指標としても有効である可能性もある.

このような認識に立てば，猛禽類にとってよい と思われる保全措置は，生態系全体にとっても良 いはずだと考えることができ，関係者の合意のも とに具体的な保全計画を立てることができそうで ある。例えば, ダムのように不可逆的な改変を加え る事業では，代償措置としてその面積に相当する 部分を事業区域周辺に確保することは不可能なの 
で, 事業とは直接関係がない地域で,クマタカなど の保護を目標に置いて環境復元を行うことや，事 業区域周辺の森林を事業の一環として適切に育成・ 管理するということが提案できる。このような行 為を直接事業者が行うことは, 現在の法的・行政的 枠組みにおいてはまだ難しいが，今後検討される ものと考えている.もち万ん，猛禽類だけで生態系 全体を扱うことは無理があり，「基本的事項」にも あるように猛禽類を含め注目種等を複数選ぶこと になろう。

\section{(2)生息環境調査の着目点と課題}

生態系アセスメントおいて, 上位性種に猛禽類 を取り上げる場合には，営巣環境も含めて地域の 環境を利用されている資源および潜在的資源と捉 えることが，各種事業の影響を把握する上で重要 である.どのような資源をどのように, どの程度改 変することになるか，代償策を実施できる場所が あるかどうかを，できる限り得られる情報で整理 しておき，不完全でもある程度定量的に予測する ことが今後は求められる.この点からは, イヌワシ やクマタカなどの上位性種の行動は，そういった 資源調査を行うべき範囲と重点的に調査すべき場 所を示すものと言え，影響を受ける種の生態に合 わせた地域の景観計画を保全措置の目標におき， 結果的に景観レベルでの生態系保全の方策を提示 できる可能性がある。

例えばクマタカは，日本の山地には隙間なく生 息していると思われ，するとどこも開発は不可能 ということになる。そうではなく現在の生息地と 潜在的な生息地を資源という観点から評価して, ある程度住民が納得できる地域の管理計画を提示 することが大事であろう.しかし, 生息環境につい てどのようなデー夕を現時点で蓄積しておくべき か, どのような管理が適切か, またそのコストの負 担をどのようにするかなどについてはまだ検討が 十分ではない。まずは猛禽類の生息を保障する森 林がもつ機能のうち何が大事か, その基準ととる べきデータと調査の体系化を行ってから，代償が 可能かどうかを判断することが基本となろう.

現在, 研究事例地は限られていて, 生息環境の変
化 (事業による改変)による各種の猛禽類の繁殖状 況の变化に関するデータは少ない.しかし,すぐに 予測·評価に用いることはできなくても, 地域の景 観の植生・地形など平面的構造と林冠など垂直的 構造についてデー夕（猛禽類の目からみた景観の 構造)を得ておくこと, 繁殖データの蓄積を行って 予測の精度向上を図ることが今後重要であると考 えられる。また，近年普及してきたG I S 用いて 経時的なデー夕を蓄積していくと, 後で解析が容 易になることが期待できる.

\section{まとめ}

·我が国の丘陵地から山岳地域では, 猛禽類が地域 の景観構造に適応して生息しており, 生態系アセ スメントにおいては，上位性にとりあげられるイ ヌワシ・クマタカ等の生息の実態を把握すること が影響評価の基礎となる。

・生態系の保全の方針や方策を求めるためには,猛 禽類の生息環境すなわち景観構造の現状を的確に 捉え, 開発計画の影響がどのような変化を起こす のかによって予測を行う.

- 複数の異なる土地利用に対する要請 (保全, 森林 利用, 開発) のバランスをとる指標として, 猛禽類 の繁殖の維持は重要であるが, まだ個体群構造·繁 殖成功度と地域の景観構造との関係などわかって いないことも多く, 開発の現場でもデー夕を蓄積 していくことが必要と考えられる.

\section{引用文献}

環境庁自然保護局野生生物課編. 1996. 猛禽類保 護の進め方（特にイヌワシ，クマタカ，オオタ カについて).

幸丸政明. 1999. 生態系のアセスメント手法. 10. かんきょう。

日本イヌワシ研究会・日本自然保護協会編. 1994. 秋田県田沢湖町駒ケ岳山簏イヌワシ調査報告書. 山崎亨. 1997. イヌワシ・クマタカの生態と生態系 保全, 66-73. 琵琶湖研究所所報第 15 号.

クマタカ生態研究グループ. 1998. クマタカ・その 保護管理の考え方一概要版一。 